and not merely in Great Britain alone. A bachelor, he was completely devoted to his College, his pupils, to astronomy and especially to the International Astronomical Union, to his comrades of the First World War, and to his duty wherever he thought it to lie. Personal convenience, comfort or profit came very low indeed on his scale of priorities. $\mathrm{He}$ was one of the most generous men I have ever met, and one of the most modest. Astronomer, soldier, don, Unitarian, internationalist, he has left the world greatly in his debt.

R. O. REDMAN

Among young intellectuals in the universities, in the years before the First World War, it was commonly regarded as a sign of feebleness of intellect to believe that war was conceivably possible; and indeed as a mark of moral obliquity to take any personal steps to meet such an emergency. Fortunately a substantial minority, in reality no less intelligent, paid rather little attention to the intellectual and moral stigma; and the following short story of a small group of them at Cambridge describes one of the earliest contributions of young scientific men to national preparedness for war.

In 1908, under the Haldane Scheme for the Territorial Army, the Officers Training Corps of the Universities took the place of the earlier Volunteers. In Cambridge, in addition to the previous battalion of infantry, units were established of cavalry, artillery, engineers and medicals. Two years later, under the imaginative leadership of F. J. M. Stratton, a Signal Company was started and before long a wireless telegraph section was formed as part of it. Encouraged by Bertram Hopkinson, professor of engineering, who lent a room in his laboratory, the wireless section began work on the design of sets for field work and it drew in a remarkable group (as it proved) of young scientists for the task. It was not possible in those days to go and buy components from dealers, and radio valves did not exist. Everything had to be built up in workshop, laboratory, or tent, by members of the section itself. Since sets had to be portable, a generator was designed to be fitted to a bicycle, and during 'operations' a member of the section pedalled steadily, if wearily, to provide power for transmission. When communication failed, for example, between Farnborough Common and Eelmore Hill, it was reestablished by flag and/or bicycle.

A photograph exists showing the ten members of the section in 1912, together with Captain Stratton commanding the Signal Company and a portable radio set complete with antenna. In it, among others, are Lance Corporal Henry Thirkill, Lance Corporal T. L. Eckersley, Private Harold Spencer Jones and Second Lieutenant A. V. Hill. Those were early days. By 1914 the wireless section had expanded considerably, and since no reserve of regular $W / T$ officers existed when the War broke out, it was natural that members of the section should be drawn into field wireless. In fact, the section provided senior wireless officers for four armies. After the War, the Signal Company was more generously treated by the War Office, and a special research group was formed inside the wireless section.

Prof. (alias Lieut.-Colonel) Stratton recalled that, among the members of his Signal Company, the following could be counted: several who went into industry, one of whom was scientific adviser to Marconi's for twenty-seven years; four vice-chancellors and five masters of Cambridge colleges; nine professors; nine Fellows of the Royal Society and three Nobel Laureates; one director of scientific research, Admiralty ; one chief engineer of posts and telegraphs, India; one secretary of the World Meteorological Organization; three successive secretaries-general of the International Council of Scientific Unions ; one Astronomer Royal ; two major-generals ; [one D.S.O.] ; one bishop ; one Colonial chief justice ; one M.P. ; and one Olympic gold medallist. This list, as its author admitted, was rather a fraud, since on the average each person in it occurred twice. Nevertheless, it is rather impressive, particularly when one remembers that two-thirds of these people served in the Signal Company during its initial years 1910-14.

\section{A. V. HILL}

\section{Dr. J. Brooks, O.B.E.}

Dr. JACK Brooks, principal scientific officer at the Low Temperature Research Station, who died in Cambridge on October 2, was in charge of the work on eggs and poultry.

Brooks joined the scientific staff of the Low Temperature Research Station in 1928 from the Muspratt Laboratory of Physical and Electro-Chemistry of the University of Liverpool, at the invitation of the late Sir William Hardy. From the outset of his career he was an individual worker, belonging to the lesscommon class of investigator who prefers to do most things for himself in the laboratory. Before the War Brooks made a name for himself in fundamental research, especially in the field of hæmatin pigments. Quite early in his career he was publishing work in the Proceedings of the Royal Society and the Biochemical Journal, and up to the outbreak of war he continued to produce a steady series of papers in his particular field of physical chemistry applied to biological systems. He then showed himself equally capable at quite the highest level in applying theoretical results to immediate practical objectives, namely, the dehydration of egg and the storage of dried material.

Brooks held an established position as the leading Government consultant in Great Britain on all matters concerned with the handling and storing of eggs. During the period $1943-47$ he was lent to the then Ministry of Food for various periods, in the course of which he visited the Argentine, United States, Canada and Australia in connexion with the Ministry's programme for the manufacture of dried egg and, afterwards, for full-scale trials of sugar-dried egg production. Later he again visited Australia as a member of the British Food Mission. After the War the emphasis of Brooks's work turned from dried to shell eggs, and again his knowledge, skill and personality were called on by the Ministry of Food to help in the solution of problems in countries exporting eggs to Britain. In 1948 and again in 1950 , he visited Poland in response to a request from the Polish Government for help in finding a solution to difficulties which had arisen in the preparation of frozen pasteurized egg in fulfilment of orders placed by the Ministry of Food. Brooks was the only person in Britain possessing the specialized knowledge for this task, and he was able to discover the cause of the trouble and suggest a solution completely satisfactory both to the Polish Government and the Ministry.

Although such calls for Brooks's services seriously interrupted his supervision of laboratory investigations, he continued to exercise a firm control over 